This item was submitted to Loughborough's Research Repository by the author.

Items in Figshare are protected by copyright, with all rights reserved, unless otherwise indicated.

\title{
Football fans' views of racism in British football
}

PLEASE CITE THE PUBLISHED VERSION

http://dx.doi.org/10.1177/1012690213506585

PUBLISHER

Sage Publications / @ The Authors

\section{VERSION}

AM (Accepted Manuscript)

\section{PUBLISHER STATEMENT}

This work is made available according to the conditions of the Creative Commons Attribution-NonCommercialNoDerivatives 4.0 International (CC BY-NC-ND 4.0) licence. Full details of this licence are available at: https://creativecommons.org/licenses/by-nc-nd/4.0/

\section{LICENCE}

CC BY-NC-ND 4.0

\section{REPOSITORY RECORD}

Cleland, Jamie, and Ellis Cashmore. 2019. "Football Fans' Views of Racism in British Football”. figshare. https://hdl.handle.net/2134/17898. 


\title{
Football fans' views of racism in British football
}

\begin{abstract}
This article analyzes 2,500 responses from association football (soccer) fans to an anonymous online survey conducted from November 2011 to February 2012 that examined the extent of racism in British football. 83 per cent of the participants stated that racism remains culturally embedded and when exploring the reasons behind its continuation from the 1970s and 1980s, Bourdieu's concepts of field and habitus proved useful for understanding why some white fans continue to express racist thoughts and behaviors at football. Central to this were explanations concerning class and education and how historical notions of whiteness remain culturally embedded for some supporters.
\end{abstract}

Keywords: Football; fans; racism; habitus; capital; whiteness

\section{Introduction}

In 1863 the English Football Association (FA) was created and as football began to expand during the latter part of the nineteenth century, a pattern began to emerge of a sport played and watched by predominantly white, working class men. For over 100 years, this pattern remained unchallenged, but from the late 1970s an increasing number of black players, including Viv Anderson, Garth Crooks, Cyrille Regis and John Barnes started playing professional football. Rather than embrace this change, a significant number of white fans subjected black players to overt and hostile racism from the terraces; some of which were infiltrated by far-right organizations (Back, Crabbe and Solomos, 2001; Garland and Rowe, 2001).

The context for this article was established in October 2011 when two on-the-field incidents of racism occurred in two separate Premier League fixtures. The first was between Liverpool and Manchester United at Anfield, and resulted in the Liverpool player, Luis Suárez, receiving an eight-match ban and a £40,000 fine for using racial terms deemed to be racist by an Independent Commission established by the FA towards Manchester United player, Patrice Evra. ${ }^{1}$ One week later, in a match between Queens Park Rangers and Chelsea at Loftus Road, John Terry (the then England captain) was eventually given a four-match ban and a $£ 220,000$ fine for the use of racist language towards Anton Ferdinand. ${ }^{2}$ As well as racist incidents occurring inside stadia, prominent black current and ex-players also faced racist abuse on the social media site Twitter, with a small number of criminal prosecutions occurring (such as twenty-one year-old Joshua Cryer who was sentenced to two years community service for the racial abuse he directed towards Stan Collymore). These incidents (and many others) went somewhat against the public presentation by anti-racist organizations that high-profile initiatives had helped to eradicate racism from football; a presentation helped by the increasing number of black players being recruited from overseas since the mid-1990s to complement the increasing number of British-born black or minority ethnic (BME) players plying their trade in professional football.

The research objective, therefore, was to encourage fans from all across Britain to provide their attitudes, views and opinions on the extent of racism in British football via an anonymous online survey conducted between November 2011 and February 2012. Although the research was not designed in a way to test or incorporate the work of Bourdieu, his conceptual framework of field (in this case, football fandom) and habitus proved useful for explaining the 2,500 fan responses. The reason is that these concepts allow for the analysis of the internalized structures and thoughts of football fans (i.e. their habits and dispositions surrounding race) in the social context of a field where anti-racism policies have existed for twenty years. 


\section{Bourdieu, habitus and the field of football fandom}

Although academic attention has been paid to the centrality of racism in the culture of football (Back et al. 2001; Burdsey, 2011; Garland and Rowe, 2001; Millward, 2008; Ruddock, 2005), there is a large void of scholarly work concerning the fan habitus (in particular around race), internal dispositions and cultural experiences of supporters engaging in British football. Although there has been varied use of 'habitus' as a conceptual framework, Bourdieu (1984) suggests that it is an embodied series of internalized dispositions, tastes, rules, habits, perceptions and expressions that are reflected in the thought processes and practices of agents and give them social meaning in their everyday life. For Bourdieu, these dispositions are so deeply ingrained that individuals are rarely conscious of them, but tend to regulate practice in such a way that reproduce distinctions and, as a consequence, inequalities. Bourdieu suggests that although these dispositions are person-specific they are compatible with objective conditions that include the social group, family and community in which one is engaged. Within the habitus, Bourdieu illustrates how opportunities and constraints created by these social conditions then help inform personal taste and practice (such as engaging in supporting a particular football team) and reflect the volume and varying kinds of capital (economic, social and cultural) each individual possesses. In any given social arena, such as the dominant culture of football fandom, Bourdieu (1984) explained how capital can be an effective way in which individuals can secure particular profits through their participation. Most notable with regards to football fandom would be social and cultural capital, which can explain how fans consume and understand the sport and how the level and rewards of membership are accrued.

The application of Bourdieu's work on the structures of class, location and family and how they interact with gender, ethnicity and life opportunities, therefore, has resonance to the field of football fandom. For example, Laberge and Kay (2002: 241) suggest social class is made up of social agents sharing the same 'interests, social experience, and value system, and who tend to define themselves in relation to other groups of agents...characterised by any kind of socially constructed trait, such as gender, age, or ethnicity'. According to Thorpe (2010: 181), the 'field refers to a structured system of social positions occupied by either individuals or institutions engaged in the same activity'. Bourdieu (1990) described the field as a game and the field of football fandom is obviously varied and comprises various power relations and key determinants with, for example, some fans watching matches alone or with friends, some choosing to attend casually or attend regularly and, more recently, others passively or actively engaged in their support (Cleland, 2010). It is clear, however, that white supporters gain the most social and cultural capital in the field of football fandom (the Premier League survey 2008/09 highlights how at least 92 per cent of supporters are white) ${ }^{3}$ and, therefore, determine the means of access. As such a popular sport, football, it can be argued, retains the power to define the cultural habits, tastes and styles of the dominant group (in this case, white) and the ways in which capital can be acquired.

Whereas Bourdieu's conceptual focus of the habitus was on class, recently (and predominantly American-based) race scholars (such as Bonilla-Silva, 2003; Bonilla-Silva, Goar and Embrick, 2006; Sallaz, 2010) have extended it to 'the structural and cultural conditions associated with an actor's location within the racialised social system' (Perry, 2012: 90). This has led to a focus on a "racial habitus", which Perry (2012: 90) suggests is 'a matrix of tastes, perceptions, and cognitive frameworks that are often unconscious (particularly for whites), and that regulate the racial practices of actors such that they tend to reproduce the very racial distinctions and inequalities that produced them'. Indeed, BonillaSilva (2003) has taken the concept of a racial habitus further by stressing the existence of a "white habitus" that regulates the practice and condition of whiteness with regards to taste, 
perception, feelings and views on matters of race and racial inequality. With some relevance to football fandom, Bonilla-Silva suggests that this promotes solidarity amongst whites and reinforces their practice, whilst simultaneously negatively stereotyping non-whites. In their analysis of race relations, Elias and Scotson (1994) used the notion of 'established-outsider relations' to explain the exclusion of less powerful groups (i.e. 'outsiders') by more established ones. When applying this to the field of football fandom, the historical acquisition of social and cultural capital by white supporters has allowed them to continue to define the culture of football fandom and how they distinguish themselves in relation to the Other (i.e. that which is distinct from or opposite).

In exploring social divisions and inequalities within British sport, an increasing number of scholars are using whiteness as a tool for examination (see, for example, Burdsey, 2007, 2009; Hylton, 2009; Long and Hylton, 2002). The notion of whiteness has been defined by McDonald (2009: 9) as 'institutionalized discourses and exclusionary practices seeking social, cultural, economic and psychic advantage for those bodies racially marked as white'. Burdsey (2009) and Hylton (2009) both make reference to the 'normalization' of whiteness in the dominant narrative of English football, at the expense of BME Others who are often marginalized.

Bourdieu (1993) states that history and social conditions help explain why agents become directly or indirectly linked with particular sporting activities. Up until the 1950s, a pattern of whiteness pervaded both British football and society. However, mass immigration occurred from the 1950s and led to the Conservative Member of Parliament, Enoch Powell, inflaming racist tension within British society by claiming in his infamous 'Rivers of Blood' speech that black immigrants were a threat to British jobs, housing and social cohesion. Scholars such as Fawbert (2011) and Thomas (2011) have explained how these underlying racist tensions within communities were exploited at football matches as young working class men were targeted by far-right groups and encouraged to engage in racist behavior in order to protect an 'imagined community' (Anderson, 1983) of national identity and belonging. For some fans, football matches provided an opportunity to air these ingrained dispositions in the relative comfort of many other like-minded white supporters. A modern example of this occurring within football comes from Fawbert (2011), who examined racial tension inside and outside West Ham United's stadium in the East End of London. Once surrounded by white working classes, immigration into the East End since the 1950s resulted in the areas surrounding the stadium now populated by British Asians. Hence, Fawbert refers to the often hostile and unpleasant experience felt by the British Asian community every fortnight when thousands of white supporters enter the area to watch West Ham play.

Evidence like the experiences at West Ham illustrate the importance of watching football for generations of white people and this cultural history continues to pose problems for racial harmony. With pertinent application to membership of a fan community, Crawford (2004: 62) argues that it is often 'defined on the basis of not only who members are, but also who they are not, and that individuals may be excluded from supporter groups on the basis of social divisions such as ethnicity, disability, gender and social class (amongst others)'. As illustrated above by Elias and Scotson (1994), this marginalization of the Other from the normative order highlights how traditional notions of whiteness and masculinity continue to pervade throughout football fandom, where the term 'one of the lads' is widely applied and adhered to (Burdsey, 2007).

Bourdieu (1993) outlines how a sport such as football should reveal the habitus of a particular social class, but the fan demographic is becoming increasingly difficult to describe. For example, in a survey conducted by the Premier League in 2005/06 on the social class of supporters, 48 per cent were in the higher socio-economic grouping AB (higher/intermediate managerial, administrative or professional) compared to 24 per cent in C1 (supervisory or 
clerical, junior managerial, administrative or professional). ${ }^{4}$ By way of contrast, the 2006 Football League Supporters survey found that 44 per cent were in the socio-economic grouping $\mathrm{C} 1$ compared to 36 per cent in AB. These results highlight some weaknesses of Bourdieu's conceptual framework, as analyzing class within modern football fandom is not straightforward; instead, we see cultural conflicts and differences occurring within this field. From a similar standpoint, Sandvoss (2005) contends that although class can be defined in socio-economic terms, social capital, education capital and cultural capital also help shape an individual's position.

Although it could be argued that the class demographic of modern football is blurred, the emotional intensity involved in fandom for some supporters still constitutes a celebration of their habitus in comparison to other supporters of the same team. Since the creation of a new Premier League in English football in 1992 we have witnessed its global expansion (helped most notably by BSkyB) and subsequent increases in overseas investment now taking place at certain clubs (such as Roman Abramovich at Chelsea and Sheikh Mansour bin Zayed Al Nahyan at Manchester City). There has also been a concentration of commercialization with large increases in admission costs as the focus quickly became clear that clubs and the league wanted a more affluent and civilized 'customer' to attend matches. Clubs focused on attracting fans from outside their traditional fan base and King (1998) argues that the increase in ticket prices forced many working class fans away from the newly built stadia; many of which were relocated out of working class, inner-city areas (where they had previously been). Changes like this led to increasing levels of resistance during the 1990s, with Nash (2000) articulating how the formation of Independent Supporters Associations at individual clubs was due to increasing tension many traditional supporters felt towards more affluent, newer ones, who it was argued did not attach the same social attachment towards 'their' club.

With regards to challenging the overt racist behavior that was present during the 1980s and 1990s, the creation of Let's Kick Racism Out Of Football in 1993 (later becoming Kick It Out in 1997) put racism and racist language at the forefront of a high-profile campaign. To try and change fan behavior, written codes of conduct were installed inside football stadia, with the threat of prosecution for those supporters guilty of engaging in racist acts. The centrality of racism within wider society was also prominent during the 1990s with the publication of the Macpherson Report in 1999 recommending a greater public emphasis on racial equality. This was the result of a public inquiry into the murder of black teenager, Stephen Lawrence, in 1993 and was quickly followed by the updated Race Relations (Amendment) Act in 2000. ${ }^{5}$

In helping justify the approach taken in this article, Carrington (2012: 965) recommends that scholars examine the 'particular importance of sports to the ways in which ideas about race circulate through social structures and mediate social relations'. Similarly, Burdsey (2011: 11) states that the aim of his book Race, Ethnicity and Football: Persisting Debates and Emergent Issues is 'to demonstrate that football is often merely the context or referent for racist behaviours or sentiments, which often manifest themselves in abstract, and sometimes novel, ways that have little (if anything) to do with the actual playing or organisation of the game itself'. This provided an opportunity to empirically assess the existence of internalized dispositions, perceptions and expressions affecting racist behavior and how capital is negotiated and accrued within the field of football fandom amongst a significant number of supporters from across Britain.

\section{Method}

The focus of this article was part of a wider investigation on the extent to which racism continued to exist in British football. A previous article (Cleland and Cashmore, 2013) focused on the existence of a 'color-blind' ideology (Bonilla-Silva, 2003) amongst football's 
governing bodies and anti-racist organizations, due to the reluctance to recognize the problem and implement policies to begin eradicating it. Due to the sensitivity of the research objective and the effort to avoid social desirability, an anonymous online survey was created. It was felt that through this method of data collection the participants would feel less inhibited and, as a result, more inclined to be open and honest about their thoughts and opinions regarding the presence of racism in football. ${ }^{6}$ It also removed the motivation to lie, or to repeat the survey, as no financial rewards or prizes were given to those who participated.

The use of an online survey has been used in previous research (Cashmore and Cleland, 2011) and has allowed for the development of a relationship with fans' forum website editors (totaling over 80 and spread all over Britain), who have responded positively to formal requests to register on their respective sites and make posts that allow for the collection of empirical data. ${ }^{7}$ The opening post always overtly states that I am an academic looking to gather fans' views towards the topic area in question and avoids the kind of 'identity deception' that be found when conducting research in an online environment (Gibbons and Dixon, 2010; Griggs, 2011).

With regards to this article, where possible, posts outlining the aim of the research were made in the 'off topic' section of message boards as to not disrupt more club-specific discussions taking place on the main message boards. Each post contained a paragraph about the research as well as a link to the online survey (www.topfan.co.uk). In some cases, the website moderator replied to my original post stating their approval, and in circumstances like this it is found to aid the data collection process (Gibbons and Nuttall, 2012). ${ }^{8}$ Due to the anonymous nature of the research, a message was included at the end of the survey reminding the participants that by clicking submit they were giving consent for their views to be used.

The data was collected over two phases between November 2011 and February 2012. Phase one centered on the emerging stories of racism and the participants were asked whether these were isolated incidents, the influence of social media, and whether the anti-racist agenda of Kick It Out, UEFA and FIFA was working. Phase two centered on whether the participants had actually witnessed or experienced racism within football, with the questions relating directly to the age they gave at the beginning of the survey. Older fans born before the 1980s (aged 30+), for example, would have been familiar with the existence of overt racism in the 1970s and/or 1980s and could accurately reflect on whether there had been a decline through the 1990s and into the twenty-first century. Those participants born in the 1980s (aged 21-30) would have become accustomed to the rise of marketable football through the creation of the Premier League as well as the move to 'civilize' crowds through the various measures discussed earlier. Younger fans would only be able to comment on more recent experiences.

Across both phases a total of 2,500 responses were received, with 1,204 completing phase one and 1,296 completing phase two. The demographic breakdown of participants illustrated that 84 per cent were male; 95 per cent were White, 3 per cent were Black/African/Caribbean/Black British and 2 per cent were Asian/Asian British; ${ }^{9} 12$ per cent were aged under 19, 22 per cent were aged 20-29, 22 per cent were aged 30-39, 21 per cent were aged 40-49, 17 per cent were aged 50-59 and 6 per cent were aged 60+.

Although pseudonyms are used on message boards as one measure to protect identity, it cannot be assumed that there is complete anonymity amongst posters. Millward (2009), for example, found that some posters actually know each other, and this could encourage posters to potentially lie or exaggerate their true feelings in the hope of impressing other users. Of course, the same could also happen for those that do not know each other (Gibbons and Nuttall, 2012). With this in mind, this article makes no claim to be representative of all football supporters, but argues that the large number of responses does provide a significant 
composition of supporter views from across Britain regarding the reasons behind the continued existence of racism.

Naturally, the project also had to consider a number of potential weaknesses. For example, it has an in-built bias to those who do not have access to the Internet, but as the Internet is available at most public libraries and on a number of smartphones and other electronic devices, it was felt this was an acceptable bias. It also had the potential problem with self-selection creating an inflated bias (Gibbons and Nuttall, 2012) as participation was voluntary, so to try and limit this bias a large number of responses were collected. To try and distribute the project and website to as wide an audience as possible, the research was also publicized on Topfan's Facebook and Twitter pages.

Analyzing the data across both phases consisted of a statistical breakdown of the closed-ended data and a thematic analysis of the open-ended data. Two social science researchers examined the open-ended data separately to minimize subjectivity before meeting to discuss the presence of thematic patterns. What shall be presented below are the results of one of the thematic patterns: namely the consistent reference to the fan habitus and how internalized dispositions, perceptions and expressions help explain the continuation of racism across British football.

\section{Results}

Even though British football has undergone huge transformations since the 1990s (both on and off-the-field), 83 per cent of the participants stated that racism remains culturally embedded. 67 per cent of those who watched football between 1990 and 1999 witnessed or experienced racism during this period; 61 per cent between 2000 and 2009; and 50 per cent since 2010. Although this suggests a decline, the following discussion analyzes how internalized racial dispositions, perceptions and importance of social and cultural capital all intersect in shaping modern fandom in British football.

\section{Internalized dispositions, perceptions and expressions towards racism}

Advocating the importance of Bourdieu's work on fans, in particular regarding how consumption preferences form the basis of fandom, Sandvoss (2005: 34) claims that the habitus functions as a simultaneous form of communication and identity:

\footnotetext{
as communication, in that our consumption choices articulate our complex class position, and as identity building, in that this communication is as much directed inwards as outwards, forming a sense of who we are and believe ourselves to be.
}

In the new circumstances facing British football, where the backgrounds of supporters are increasingly unknown, observations of their habitus (tastes, dress, and behaviors) provide important information about them (Bourdieu, 1990). Although there is likely to be some variety in the habitus of modern supporters, there is also likely to be some commonality amongst them also in terms of appearance, clothing, behavior and expression at matches. Addressing this, Bourdieu (2000) recognizes a 'split' within the 'typical' construction of a habitus, thus complicating any analysis of white football supporters as fan practices vary from one fan to another. Two supporters of the same team, for example, can identify themselves as supporters, but express their fandom and gather social and cultural capital in different ways. For one, wearing the team's colors could symbolize their practice, but for the other this could associate with a newer form of fandom, and is therefore resisted (King, 1998; Nash, 2000). Similarly, becoming involved in chanting team songs could mean more to some fans, whilst for others their sheer presence in the crowd is enough to justify their support. Therefore, although there are similarities in the practice of consumption amongst a number of 
supporters, there are also variations that 'are increasingly indicative of social and cultural differences' (Sandvoss, 2005: 38).

Following similar findings raised by Mennesson (2010), some participants, including this Southampton fan (white, male, 40-49), indicate individual differences with regards to the internalized dispositions, perceptions and expressions of supporters:

Each individual is responsible for their own thoughts and they are developed throughout their life experiences from childhood through to adult socialisation. With many footballers coming from different cultures there is bound to be a mix in beliefs, even though that may not be right.

As part of their article looking at ethnic supporter representation in football, Burdsey and Randhawa (2012: 107) call for a 'nuanced approach that addresses how race, ethnicity, religion, gender and class interlink to affect fans' experiences'. Similar calls have been found elsewhere with Fawbert (2011) also arguing for the central positioning of class in any analysis of football fandom and racism. Indeed, discussions around class and cultural and social difference were significant within the data: 'Racism is like a cancer from the grassroots all the way to the top. It comes down to social class, education, respect and culture', said one Chelsea fan (white, male, 30-39), whilst a Fulham supporter (white, female, 40-49) concurred: 'Sadly racism is deeply rooted in white English working class society and hence among football fans from that background'. However, it is too easy to lay the blame of the continued presence of racism solely at the door of working class fans. As highlighted earlier, recent surveys conducted by the Premier League and Football League outline a significant number of supporters in the social grades $\mathrm{AB}$ and $\mathrm{C} 1$.

Despite the promotion of anti-racism campaigns since the mid-1990s, a number of fans argue that the continuation of racism from the 1970s and 1980s outlines how culturally ingrained racism is in the habitus of some supporters. This Tottenham Hotspur fan (white, male, age 30-39) condensed the views of many participants from across Britain who suggest that internalized dispositions and expressions regarding race spread from one white generation to the next and are embedded in the habitus and cultural practice of some white communities:

Ignorance is passed down through the generations. Racism will always be rife unfortunately. The history of football clubs are embedded in local inner-cities and people who live in these areas have a 'world is against us' approach to life. Anyone who is not in that 'community' is seen as an 'outsider'.

Examples like those raised so far highlight the "white habitus" in which British football has historically operated in. By following generations of family, communities and similar social groups in watching football, notions of whiteness have clearly become ingrained in the ways in which the practice of football fandom has been regulated for a number of white fans. In some cases, where support from likeminded peers gains approval, racist beliefs and behavior can reinforce or even enhance an individual or groups position within the field of football fandom (such as the 'established-outsider' notion suggested earlier by Elias and Scotson, 1994).

A number of fans made reference to the existence of racism in fans aged over 40 , thus supporting the statistical findings that racism has remained present in some form since the 1980s. 'I feel that racism remains present in old school football fans', said this Stoke City fan (white, male, 50-59), 'any racism I hear at football tends to come from more older supporters (those aged 40-50), rather than younger ones. I hope that it dies out with this generation'. This Blackburn Rovers fan (white, male, 50-59) shared similar thoughts:

Racism is unfortunately embedded in British culture and will take at least another 40 years to root out. The younger generation ( 25 or less) have been brought up with less clouded views and in turn 
are less likely to be racist. The older generations are still about 'the foreigners coming over here and taking our jobs', or living off benefits.

As stated earlier, older white fans would have started watching football when the players were primarily white, and as Mennesson (2010: 6) argues, 'the more long-lasting, the stronger, and the more concerned by emotional relations a socialization process is, the stronger the constructed dispositions will be'. Likewise, Sallaz (2010: 296) contends that 'individuals who came of age in one racial formation will tend to generate practices that simultaneously preserve entrenched racial schemata'. This is despite football presenting itself as anti-racist, yet for some supporters and their racial habitus, this can be openly contested.

Indeed, the recent public attention given to supporters being arrested inside football stadia highlights a pattern that supports these claims. For example, in an FA Cup tie between Liverpool and Manchester United in January 2012, 58-year-old Liverpool supporter, Phillip Gannon, was given a four-year football banning order after being captured on live television making monkey gestures towards Patrice Evra. Similarly, in covert footage captured by Sky Sports and released in February 2013, 53-year-old Millwall supporter, Gerrard Scanlon, subsequently admitted a racially aggravated public order offence towards Leeds United striker, El-Hadji Diouf, and was given a football banning order for five years. However, it would be a mistake to assume that racism lies solely with older supporters, as the recent arrests made via racist abuse on Twitter discussed earlier prove that this remains a problem for all generations of football supporters.

The Evra/Suárez, Terry/Ferdinand cases and increasing influence of social media (such as Twitter and some online fans forums) as a vehicle to express racist thoughts highlight the complexity of analyzing contemporary racism in multicultural Britain. As stated by Sallaz (2010: 294) the 'dispositions of the habitus should prove durable and may even improvise new practices that transpose old racial schemata into new settings'. Technological changes have provided individuals with the opportunity to express racist dispositions in a very covert way, such as through the use of a computer or smartphone. As one Burnley fan (white, male, 20-29) stated: 'Off the pitch the outlet available on social media is a very $21^{\text {st }}$ century way of unleashing old prejudices without restraint'.

For some fans, the issue of racist intent is a grey area, with some suggesting that any negative reference to race is racist, whilst others suggest it is a poor choice of language. In examining supporters of Millwall, Robson (2000) found that fans do not see themselves as racist. Instead they portray their behavior at football matches (including the use of racist language) as one of doing whatever they can for their team to win. In the case of racism, this often referred to as 'banter' and by engaging in this practice, the argument is that it gives them social and cultural meaning (Bourdieu, 1990). As one Manchester City fan (white, male, 30-39) explained:

John Terry calling Anton Ferdinand a black whatever is a world away from bananas being thrown at black players and monkey noises in the 1970s. That was real racism, a belief that black players (and people) were inferior. What is displayed now by Suárez and Terry is a poor choice of language.

A Middlesbrough fan (white, male, 50-59) shared similar thoughts:

I am not sure how much of it is pure racism, and how much is more about the way that racist language has developed. It's so easy to allude to someone's colour, sexuality or gender when they do something you don't like, provided they are Black/Asian, gay or female, because previous generations really think like that. 
Although some white fans feel that they can gain social and cultural profit by participating in racist behavior, for the majority of fans, there is no grey area and any negative reference to race needs to be seen as racism. For example, this West Ham fan (white, male, 30-39) summarized the thoughts of many who argue that society needs to be less prejudicial towards the BME community:

There is a huge ignorance among the general population about what is and what is not racist, and great denial and resistance to see racism in their attitudes, in their use of language or stereotypes, or in the discussions of the value of different ethnicities, as if one ethnicity was somehow inevitably better than another, or the belief that people can 'choose' their ethnicity.

Burdsey’s work on BME British football players (2007) and cricket players (2010) highlights the importance of being 'one of the lads' through the participation in the dominant cultural habitus of their white team mates. In situations like this, where racist comments are reduced to jokes, the culture of racism remains perpetuated amongst some white football fans as these views remain unchallenged and reinforces their position within the field of football fandom.

\section{Everyday practice and social meaning}

Although Islamophobia was present before 9/11, this event increased the prejudices Muslims felt in most parts of the Western world. Inflamed by the reference to terrorism by some sections of the media, Saeed and Kilvington (2011) suggest that racist dispositions have moved away from a biological focus to one of cultural difference that increasingly draws on whiteness, national identity and belonging that culminate in a marginalization of the Other. Within football, Burdsey and Randhawa (2012) and Fawbert (2011) state how Muslims living in close proximity to particular stadia often suffer from racial harassment on match days. Indeed, racist organizations such as the English Defence League continue to offer opportunities for white supporters to express racist dispositions in their everyday practice. Views like this are also recognized by supporters, with this Gillingham fan (white, male, 4049) stating:

Explicit, deliberate racism has, for the most part, decreased significantly over the last thirty years, both for society in general and at football matches. Equally, newer forms of racism have surfaced - notably in relation to Islamophobia - and this receives little or no attention.

As Modood (2007) has stressed, reference to the Other, in this case Muslims, threatens 'Britishness' (even if they were born here) and leads to social alienation. In basing his article on empirical findings about Muslims in Britain, Wright (2013) suggests that less than one in four people feel that following Islam is compatible with a British way of life. Instead he argues that there is a widespread anti-Muslim sentiment existing throughout the UK.

Some scholars are critical as to the influence some media outlets have on society, with Saeed and Kilvington (2011: 602) arguing that stories are 'commonly written and spoken about in a tone which suggests anxiety over the erosion of the perceived 'indigenous' national culture'. Recently, much of the rhetoric in Britain has concerned welfare and the debate concerning 'scroungers' versus 'strivers'. For Bonilla-Silva (2003), examples like this only inflames social tension and ultimately can lead to the racial habitus often unconsciously reproducing racial difference and inequalities through the perception that certain groups (such as immigrants) receive preferential treatment off the state. Pointing the finger of blame at the Other for the perceived problems facing British society, this Coventry City fan (white, male, 30-39) argued:

The only way to combat these thoughts in people is to have a fair and just society. Feelings of injustice are actively promoted; just look at the recent riots where the rioters were portrayed as 
mainly black and claiming benefits. This justified the ideologies of far right organisations and gave them some legitimacy. It's always easier to blame people for your troubles who are different to you.

Other participants, including this Leicester City fan (white, male, 20-29) shared similar thoughts:

On the whole society is less racist than it was before, but the preference in society seemingly given to ethnic minorities and the gradual erosion of British culture may have something to do with the build-up of resentment towards these minorities. This is the question that no-one seems to be willing to address or even acknowledge - until it is then the resentment will keep building.

In responses like this, participants from across Britain attempted to link the existence of racism within football to a number of wider societal problems they deemed were responsible for such expressions. On this point, Williams, Dunning and Murphy (1989) remain uncertain as to whether racist views emerge in society, which are then transmitted into football, or whether the passion and prejudices that football conjures up in people enhances racist beliefs. For a number of participants, however, this link is clear, as outlined by this Glasgow Rangers fan (white, male, 30-39): 'Racism resurfacing in society in general is probably linked to hard economic times. It is not football that is racist but parts of society are. Football is a reflection of society. As long as you have deep rooted racism in society it will appear in and around football'. In trying to justify the continued existence of racism inside football stadia, this Newcastle United fan (white, male, 20-29) stated: 'It is not football's problem - it is society's problem. Football happens to be a place where emotions run high, fear kicks in, and anger gets vented'. Other fans drew on the response by the Coalition government in 2012 to get involved in tackling all forms of discrimination present within modern football as evidence that the government recognizes the social significance of football in the everyday practice of millions of people across Britain. ${ }^{10}$ For this Rochdale fan (white, male, 40-49), governmental intervention was inevitable:

Combined with the current racial tensions in our society brought about by what some see as positive discrimination and extremes of political correctness, this issue is far more complex and intertwined with other issues than a simple game of football. Personally, I welcome governmental intervention as it raises the bar and will put some pressure back on to the FA.

\section{Challenging the habitus and dispositions of fans}

So, what can be done? The problems of attempting to change internalized racial dispositions are clear, not least in what was identified by this Aston Villa fan (white, male, 40-49):

It is difficult to challenge the minority that have racist views. These views are often present from childhood and built into the mind-set of individuals. Simply fining or even jailing them will not have much impact. And banning orders are easy to evade. Racism is like a cancerous tumour: it's going to need some pretty deep surgery to tackle it.

Gillborn's (2008) research on the British educational system argued that it has too often focused on the most blatant examples of racism and has not spent enough time acknowledging or addressing the prejudices that exist within society. Likewise, Randhawa (2011) calls for greater resources and capacity that allows for anti-racist organizations to deliver, within a range of settings, racial equality programs that begin to effectively tackle racism and promote tangible targets where sustainable change becomes evident in the behavior of football fans. Approaches like this found support within the data, with this Derby County fan (white, female, 30-39) suggesting that a focus on educating younger people 
would work and would have long-term benefits in making football an environment welcoming of all races and backgrounds:

Bring this issue into schools. After all, school is where many cultures, backgrounds and nationalities spend most of their time together. If we can instil a good understanding of each other it will follow our children through to adulthood.

However, anti-racism education also has potential limitations and problematic features and, as suggested earlier, can lead to the racial habitus being presented in overt and covert ways. Hewitt (2005), for example, suggests that focusing on white working class communities can lead to a 'white backlash' if they feel that their behavior and language is seen as 'racist' and they are judged negatively because of it. As highlighted by Bourdieu (1984: 211), 'it would be naïve to suppose that all practitioners of the same sport (or even any other practice) confer the same meaning on their practice or even, strictly speaking, that they are practicing the same practice'. Indeed, a focus on racist behavior does not address wider social prejudices held in the habitus of some supporters and misplaced interventions such as anti-racism campaigns that aim to treat the dispositional system could actually strengthen opposition to them (King, 2000). The delicacy of this balancing act was found within the data, with this Manchester United fan (white, male, 20-29) stating: 'Football is a microcosm of the society in which it is operating - racism is eradicated by education and not by legislation but does take longer and runs the risk of people rejecting being told how to think'.

Although a focus on education was a consistent suggestion as to how racism can start to be effectively tackled, some fans refer back to the habitus of some white supporters by suggesting how internally embedded dispositions surrounding race are for some people and thus a focus on education alone would be futile. As this Liverpool fan (white, male, 40-49) stated:

Racist views are present from childhood in some fans and then built into their mind sets. For some fans, this is just impossible to eradicate. Education is unlikely to work for supporters who may never have been to school.

Thus, whilst firm action against any form of racist behavior would be welcomed by a significant number of white football supporters, the constant presentation of 'official' antiracism campaigns can be seen by some fans as negatively labeling them as racist. Therefore, as suggested by Bourdieu (1984, 1990), internalized dispositions, even those that allow for the presentation of racism, govern the thought process of particular agents and give them social and cultural meaning in their everyday life.

\section{Conclusion}

This article has demonstrated how Bourdieu's concepts of field and habitus can help in explaining the continuation of racism in football. In expanding his conceptual framework, the empirical evidence has highlighted the existence of a racial habitus (Bonilla-Silva, 2003; Bonilla-Silva et al. 2006; Perry, 2012; Sallaz, 2010) and how this normalizes whiteness by giving power and specific social and cultural profits to white supporters through their participation in the game. Despite an increasing number of black footballers and a focus on anti-racism, football remains an environment where internalized dispositions, perceptions and expressions towards race continue to be displayed. In this way, the empirical evidence suggests that football can be viewed as a symbol of social division and exclusion that continues to influence the meanings some white supporters attach to football fandom.

Even though racist dispositions retain a presence in football for some white supporters, the permanence of them can be questioned as British football does not witness the level of racism that affected the sport in the 1970s and 1980s. According to Mennesson (2010), 
modern sporting tastes and practices do not lead to a straightforward analysis of class; rather multiple and contradictory dispositions are now affected by multiple socialization processes. With regards to football fandom, cultural conflicts occur because of the mixture of classes now found to be consuming the game. It is too simple to point the finger of blame for the continuation of racist thoughts, expressions and behaviors at the working classes as the recent examples of fans being charged with racist behavior has proved - it is more socially and culturally widespread than that.

As the demographic of the football fan continues to evolve, and the everyday experience of opportunities, resources and capital continue to differ, for fans who feel that their lives remain constrained in unequal ways, the way they think and interact with the Other is unlikely to change. This is evident in the increasing academic coverage given to subjects like whiteness, national belonging, identity and Islamophobia and how this is applied to society as well as the sporting context (Bonilla-Silva, 2003; Hylton, 2009; Long and Hylton, 2002; Modood, 2007; Saeed and Kilvington, 2011).

Overall, old habits die hard and the social and cultural meaning attached towards football and the level of capital acquired through this have remained the same for some white supporters (Bourdieu, 1984, 1990), even after the attempted sanitization of football fandom in the mid-1990s. Some fans resist the prescribed norm of how to behave inside and outside football stadia and this is the challenge facing anti-racism campaigners and football's authorities. For the majority of participants, the FA and anti-racist organizations need to work harder with fan groups to change public stereotypes of black and ethnic minorities and, if implemented successfully, is likely to improve the playing and spectating environment. What this article has illustrated is that eradicating racism remains a significant challenge to what many still insist on calling 'the beautiful game'.

\section{Acknowledgements}

We would like to thank the three anonymous reviewers for their insightful and helpful comments on an earlier version of this article.

\footnotetext{
${ }^{1}$ See: http://www.bbc.co.uk/sport/0/football/16186556, accessed 20 December, 2011.

${ }^{2}$ See: http://www.bbc.co.uk/sport/0/football/19842795, accessed 5 October, 2012.

${ }^{3}$ See: http://www.epfl-europeanleagues.com/changing face.htm, accessed 20 April, 2012.

${ }^{4}$ See: http://www.abc1demographic.co.uk/ for a description of social grades.

${ }^{5}$ This subsequently became part of the 2010 Equality Act.

${ }^{6}$ In designing a survey to test the research question, the ethical process of the British Sociological Association was adhered to - see http://www.britsoc.co.uk/media/27107/StatementofEthicalPractice.pdf, accessed 5 November, 2011.

${ }^{7}$ A registered user on a message board can start a new conversation (or post) by creating a title and writing some text that fellow users can read and respond to.

${ }^{8}$ Most message boards have moderators who monitor discussions taking place to ensure that they do not break the terms and conditions of the website.

${ }^{9}$ The categories for ethnicity were based on the 2011 UK Census - see:

http://www.ons.gov.uk/ons/rel/census/2011-census/key-statistics-for-local-authorities-in-england-and-wales/rptethnicity.html

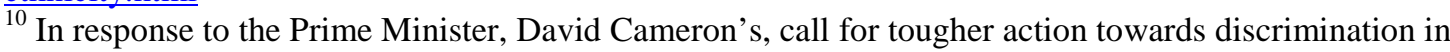
football, the FA submitted a 93-page document in December 2012 highlighting how this was going to be implemented: http://www.bbc.co.uk/sport/0/football/20672812, accessed 11 December, 2012.
} 


\section{References}

Anderson B (1983) Imagined Communities: Reflections on the Origin and Spread of Nationalism. London: Verso.

Back L, Crabbe T and Solomos J (2001) The Changing Face of Football: Racism, Identity and Multiculture in the English Game. Oxford: Berg.

Bonilla-Silva E (2003) Racism without Racists: Color-Blind Racism and the Persistence of Racial Inequality in the United States. Lanham: Rowman and Littlefield.

Bonilla-Silva E, Goar C and Embrick D (2006) When whites flock together: The social psychology of white habitus. Critical Sociology 32: 229-53.

Bourdieu P (1984) Distinction: A Social Critique of the Judgement of Taste. London: Routledge and Kegan Paul.

Bourdieu P (1990) The Logic of Practice. Cambridge: Polity Press.

Bourdieu P (1993) The Field of Cultural Production. Cambridge: Polity Press.

Bourdieu P (2000) Pascalian Meditations. Cambridge: Polity Press.

Burdsey D (2007) British Asians and Football: Culture, Identity, Exclusion. London: Routledge.

Burdsey D (2009) Forgotten fields? Centralizing the experiences of minority ethnic men's football clubs in England. Soccer and Society 10: 704-21.

Burdsey D (2010) British Muslim experiences in English first-class cricket. International Review for the Sociology of Sport 45: 315-34.

Burdsey D (2011) Race, Ethnicity and Football: Persisting Debates and Emergent Issues. London: Routledge.

Burdsey D and Randhawa K (2012) How can professional football clubs create welcoming and inclusive stadia for British Asian fans? Journal of Policy Research in Tourism, Leisure and Events 4: 105-11.

Carrington B (2012) Introduction: Sport matters. Ethnic and Racial Studies 35: 961-70.

Cashmore E and Cleland J (2011) Why aren’t there more black football managers? Ethnic and Racial Studies 34: 1594-1607.

Cleland J (2010) From passive to active: The changing relationship between football clubs and football supporters. Soccer and Society 11: 537-52.

Cleland J and Cashmore E (2013) Fans, racism and British football in the twenty-first century: The existence of a 'colour-blind' ideology. Journal of Ethnic and Migration Studies. Available: http://www.tandfonline.com/action/showAxaArticles?journalCode=cjms20 (accessed March 21, 2013).

Crawford G (2004) Consuming Sport: Fans, Sport and Culture. London: Routledge.

Elias N and Scotson J (1994) The Established and the Outsiders ( $2^{\text {nd }}$ Edition). London: Sage. 
Fawbert J (2011) 'Wot, no Asians?' West Ham United fandom, the cockney diaspora and the 'New' East Enders. In: Burdsey D (ed.) Race, Ethnicity and Football: Persisting Debates and Emergent Issues. London: Routledge, 175-90.

Garland J and Rowe M (2001) Racism and Anti-Racism in Football. Basingstoke: Palgrave.

Gibbons T and Dixon K (2010) 'Surfs up!': A call to take English soccer fan interactions on the Internet more seriously. Soccer and Society 11: 599-613.

Gibbons T and Nuttall D (2012) Using e-surveys to access the views of football fans within online communities. Sport in Society 15: 1228-41.

Gillborn D (2008) Racism and Education: Coincidence or Conspiracy? Abingdon: Routledge.

Griggs G (2011) Ethnographic study of alternative sports by alternative means: List mining as a method of data collection. Journal of Empirical Research on Human Research Ethics 6: 85-91.

Hewitt R (2005) White Backlash: The Politics of Multiculturalism. Cambridge: Cambridge University Press.

Hylton K (2009) 'Race’ and Sport: Critical Race Theory. London: Routledge.

King A (1998) The End of the Terraces: The Transformation of English Football in the 1990s. London: Leicester University Press.

King A (2000) Football fandom and post-national identity in New Europe. British Journal of Sociology 51: 419-42.

Laberge S and Kay J (2002) Pierre Bourdieu's sociocultural theory and sport practice. In: Maguire J and Young K (ed.) Theory, Sport and Society. London: JAI, 239-66.

Long J and Hylton K (2002) Shades of White: An examination of Whiteness in sport'. Leisure Studies 21: 87-103.

McDonald M (2009) Dialogues on Whiteness, leisure, and (anti)racism. Journal of Leisure Research 41: 5-21.

Mennesson C (2010) Gender regimes and Habitus: An avenue for analysing gender building in sports contexts. Sociology of Sport Journal 29: 4-21.

Millward P (2008) Rivalries and racisms: ‘Closed' and 'open’ Islamophobic dispositions amongst football supporters. Sociological Research Online 13. Available:

http://www.socresonline.org.uk/13/6/5.html (accessed 12 April, 2012).

Millward P (2009) Getting 'into' Europe: Identification, Prejudice and Politics in English Football Culture. Staarbrucken: VDM Verlag.

Modood T (2007) Multiculturalism. Cambridge: Polity.

Nash R (2000) Contestation in modern English professional football. International Review for the Sociology of Sport 35: 465-86. 
Perry S (2012) Racial habitus, moral conflict, and white moral hegemony within interracial evangelical organizations. Qualitative Sociology 35: 89-108.

Randhawa K (2011) Marrying passion and professionalism: Examining the future of British Asian football. In: Burdsey D (ed.) Race, Ethnicity and Football: Persisting Debates and Emergent Issues London: Routledge, 237-50.

Robson G (2000) No-one Likes Us, We Don't Care: The Myth and Reality of Millwall Fandom. Oxford: Berg.

Ruddock A (2005) Let's kick racism out of football - and Lefties too! Journal of Sport and Social Issues 29: 369-85.

Saeed A and Kilvington D (2011) British-Asians and racism within contemporary English football. Soccer and Society 12: 600-10.

Sallaz J (2010) Talking race, marketing culture: The racial habitus in and out of apartheid. Social Problems 57: 294-314.

Sandvoss C (2005) Fans: The Mirror of Consumption. Cambridge: Polity.

Thomas P (2011) Marching altogether? Football fans taking a stand against racism. In: Long J and Spracklen K (ed.) Sport and Challenges to Racism. Basingstoke: Palgrave, 185-98.

Thorpe H (2010) Bourdieu, gender reflexivity, and physical culture: A case of masculinities in the snowboarding field. Journal of Sport and Social Issues 34: 176-214.

Williams J, Dunning E and Murphy P (1989) Hooligans Abroad: The Control of English Fans in Continental Europe ( $2^{\text {nd }}$ Edition). London: Routledge.

Wright O (2013) Baroness Warsi: Fewer than one in four people believe Islam is compatible with British way of life. Independent, 24 January. Available:

http://www.independent.co.uk/news/uk/home-news/baroness-warsi-fewer-than-one-in-four-peoplebelieve-islam-is-compatible-with-british-way-of-life-8464026.html (accessed 24 January, 2013). 